\title{
Motivational Strategies In Teaching Speaking Skill
}

\author{
Arofiatus Sa'diyah \\ Universitas Muhammadiyah Malang, Jawa Timur, Indonesia \\ Malang \\ E-mail: ophieopie@yahoo.com
}

\begin{abstract}
Motivation plays an important role in learning process, but it is generally known as the main problem in English as foreign language learning process. Most of the researches and studies pay high attention to this problem as it seems to be the trickiest challenges faced by teachers. Moreover in teaching speaking, the teacher should have high sensitivity to identify whether the students really have low motivation in oral production or it is caused by other factors, because low of motivation makes the students unable to achieve the goal of language learning. This paper discusses the motivational strategies in teaching speaking skill to the students who has low motivation also provide recommendation for English teacher to have successful implementation regarding to solve student' low motivation in speaking skill.
\end{abstract}

Keywords: Motivational strategies, teaching speaking skill

\section{Introduction}

Of all thorough researches and studies concerning problems in teaching foreign language, many different problems were related to curriculum, learning process, facilities, classroom management, problem faced by the student itself such as: personality, anxiety, environment, and etc. From all of those problems, one problem seems to be consistently exists as a challenge for teachers is student's motivation. Motivation means a cluster of factor that 'energizes' the behavior and give it direction (Atkinson 2000:13). It is term to describe what energize a person to do the activity. It is kind of internal drive which pushes someone to do things in order to achieve something. It means when someone is motivated it will create an action or change. Student's low motivation is one of problems that undeniably stay unsolved from time to time. Much research has been conducted to solve the problem on student's motivation in learning language. Lamb (2013 in Astuti 2013) who conducted a research to 11-12 years old children's English learning motivation in the Indonesian context. His findings indicated that student motivation both instrumental and integrative motivation in relation to learning English as a global language is high. In the conclusion Lamb suggested that the English teaching methods and materials be changed. A limited amount research has been conducted to find out the effect of implementing motivational teaching strategies on students' motivation such as: nine studies have used Dornyei's motivational strategies and found the correlation between teacher motivational strategies and students' motivation. In this paper the writers implement motivational strategies to arouse students' motivation, because those strategies have impact on students' motivation-in this case is English learning process especially in speaking skill.

Ur (2012:117) considered speaking as the most important skill among four skills (listening, speaking, reading, and writing) because people who know a language are referred to as speakers of that language. However Zhang (2009) stated that the most difficult skill among four skills is speaking, because the teaching learning goal is to aim at maximizing individual language use. Then when student have low motivation, it becomes challenge for the teacher to solve the problem. The purpose of this paper is to show that although motivation has already drawn so much attention, but it still is lingering around learning process analysis hardly with very few solutions. Besides, this paper will help in determining one problem with motivation of students in higher education, the implication as well as proposing motivational strategies in teaching speaking to the students who have low motivation.

\section{Discussions}

\section{a. Motivation}

Motivation comes from Latin verb movere which means "to move", Dörnyei and Ushioda defined motivation as what moves humans to make certain choices, to engage, expend, and persist in action or behavior (Dörnyei and Ushioda, 2011:3, in Walker, 2011:3). Motivation is the driver of human action for special purpose, when someone has motivation means he/she moves to do something. Moreover in language learning, with motivation the students will achieve the goal to learn the target language. Harmer, J (2001:51) devided motivation into two, extrinsic (outside) and intrinsic (inside) motivation. In this case, in language learning, extrinsic is caused by any number of outside factors, such as reward, punishment, etc. And intrinsic comes from within the individual 
itself. The students are motivated by the enjoyment of learning process or by a desire to make themselves feel better. Intrinsic is especially important for achieving success, the goal of learning can be achieved when the students come to love their learning process. It is undeniably a strong driving force for students to behave in a specific way.

Why motivation is important in language learning? Once again, human behaviour is a complex entity. Human can behave differently based on different personalities, experience, purposes, etc (Dörnyei, 1998:126). Significant differences among students are often visible during classroom interaction. Some of the students are highly active, some are talkative, while others are passive and even seem to be not interested at all. What are the reasons behind all these? Are they simply too motivated or not too motivated to be involved in class? This is a tricky task for teachers. In language learning, Harmer, J. (2001:52) stated that the source of motivation come from four aspects: 1. the society we live in (make the students realize that learning English is important, the environment has big influence on this), 2. significant others (need support from others e.g. parents, siblings, etc), 3. the teacher and 4. the method. When all aspects mentioned are fulfilled, it supports the students to be motivated in the teaching learning process.

Some prior studies had been conducted under this topic. Walker (2011) examined the motivation in language learning on Asian students in high school level. In his paper, he mentioned factors contributed to students' demotivation and tried to link it with teacher's performance. In his opinion, teacher's performance can influence students' motivation to learn. Dörnyei (1998) explained the complicated concept of motivation related to psychological aspect and defined the influence of motivation in language learning. Dörnyei then moved further in his book to talk about motivational strategies in which it was a more practical approach, to introduce how to generate and maintain students' motivation. Meanwhile, Aydin (2012) took a different path in researching about motivation in language learning, which is to learn about how teachers might lose motivation in teaching. What distinguishes this paper from those prior studies is that this paper will show motivational strategies used by the teacher in teaching speaking, then the teacher can measure the ability and competency of students' oral production.

\section{b. Teaching Speaking and Motivational Strategies}

Related to Ur (2012) argued that Speaking is often considered as a neglected skill among four skills. It is neglected because speaking itself contains linguistic and non-linguistics elements, such as: pronunciation, intonation, articulation, expression and so forth. In this case, considering its features and difficulty to master, motivation is helpful to realize teaching and learning speaking for the students. Ur (2012: 118) argued that in teaching speaking, the teacher will find some problems faced by the students as the challenges for the teacher, they are:

1. Shyness and Inhibition. Students are worried to make a mistake, fearful of criticism, and simply shy of the attention that their speech attracts.

2. Finding things to say. The students cannot think anything to say, they need to read and explore more before they speak, so that it is worth making the effort to speak.

3. Low Participation of Individuals. The goal of teaching learning in speaking is to aim at maximizing individual language use. But sometimes because of minimum time or large participants, it creates lack of participation. Moreover the tendency of some students is too dominate, while others have little chance to speak.

4. L1-use. Students who share the same mother tongue tend to use it because it is easier and because students feel less exposed if they are speaking their mother tongue.

In addition, based on the journal result conducted by Zhengdong Gan (2012) on Australian Journal of Teacher

Education, he concluded the students' problem in speaking skill as follows:

1. Inadequate vocabulary

2. Grammar as stumbling block

3. Imperfectly Learned Pronunciation and Intonation

4. Inadequate Opportunities to Speak English in Class

5. Lack of a Focus on Language Improvement in the Curriculum

6. Input-Poor Environment Outside Class

From the non linguistics problems above, the writer concludes one problem that seems to be consistently exists as a challenge for a teacher that is student's motivation. The entire problems above can be solved when the students have motivation. Actually - motivation is the crucial force which determines whether a student embarks in a task at all, how much energy he devotes to it, and how long he preservers (Littlewood, 1984, p.53). The development of communicative skills can only take place if students have the motivation and opportunity to express their own identity and relate with the people around them (Littlewood, 1981). Good motivation in teaching learning will create good achievement too. 
Bahadorfar in her journal (2014) stated that the important of teaching speaking are: speaking is a crucial part of second language learning and teaching; the speaking mastery is a priority for many second language students; the improvement of spoken language proficiency determines the students' success in language learning; oral skill have hardly been neglected in today's EFL/ESL courses. As speaking becomes neglected skill among the four skills, in teaching speaking the teacher should produce good oral production as a model to the students. Nunan (2003) stated that the teacher should produce the English speech sounds and sound patterns; use word and sentence stress, intonation patterns and the rhythm of the second language; select appropriate words and sentences according to the proper social setting audience, situation and subject matter; organize their thoughts in a meaningful and logical sequence; use language as a means of expressing values and judgments; use the language quickly and confidently with few unnatural pauses, which is called as fluency.

Moreover, related to the speaking activities such as: discussion, debate, presentation, role play, etc. Harmer (2001: 276) argued that there are three role of teacher that can be applied during speaking activities, they are: as prompter, participant, and feedback provider. As prompter, it is needed when the students gets lost and cannot think what they want to say, then the teacher's role is giving a clue, or helping them to interpret what actually they want to deliver. And as a participant, the teacher change his/her role as a student that participate in any discussion or role play, also there, the teacher will be good example for the students. Besides it will create good interaction between the students and the teacher and create creative atmosphere during the activity, because indirectly the teacher still lead the whole activity but not dominant. And as feedback provider it helps the students solve their misunderstanding and hesitation during the activity. Giving feedback depends on the teacher's tact and appropriacy of the feedback in particular situation. When the students complete their activity, the teacher should assess what the students have done and giving the feedback and correction

Beside, in teaching speaking the teacher will find many challenges related to the problem faced by the students that have already mentioned above, especially when the students have low motivation in creating oral production. As a result, the students avoid the tasks; they always say "why do we have to do this?" when they are asked to do the assignment; the students give up easily; the students can be seen that they have behavior problem, display social immaturity, have low self-esteem and self confidence with regard to schoolwork, have lack academic skill necessary to complete work, have lack organizational skill, feel bored easily (Ken: 2001). So what teacher should do is to change the students' though, change their mindset. And figure out what something make them interested or motivated related to the leaning process activities. Here the writer tries to provide motivational strategies to arouse students' motivation in speaking.

Motivational strategies are new approach to explore the motivation in TEFL. Fu Xiao (2013) in his journal untitled "Motivational Strategies in Teaching English as Foreign Language--------Applying Motivation plan in TEFL" applied motivational strategies that are devided into four components according to Dornyei (2001): creating the basic motivational conditions; generating initial motivation; maintaining and protecting motivation; and encouraging positive retrospective self-evaluation. In this model, the most difficult question is: how can I know if and when the students are motivated? In fact, based on the present state of knowledge in the field of motivation, it is currently impossible to accurately respond to this question. Although we cannot precisely evaluate the motivation of students, there are several approaches we can use to estimate and increase our awareness of the presence and quality of motivation among the students.

On the other hand, related to other journals about motivational strategies that conducted by Hapsari (2013) stated that motivated language teacher plays essential role in building and developing students' motivation in the classroom. She argued that motivation can be manipulated through certain instructional or motivational strategies. The motivational strategies applied are defined as method and techniques to generate and maintain the students' motivation. In Her journal stated (Renandya: 2013) proposes four types of motivational strategies to arouse students' motivation in the classroom. The four types of motivational strategies include:

1. Teaching methods, teaching methods should be variety. The more teacher improve and develop their teaching methods and strategies, the more successful; they will be in engaging the students in learning activities or task.

2. Tasks, tasks that allowed the students to experience more success rather than failure are a great boost to students' motivation.

3. Texts, both oral and written instructional texts and materials used as classroom materials should be interesting and relevant to the students. Text here means the material used in teaching learning. Moreover, the instructional texts should be engaging cognitively, affectively and socially.

4. Tests, test as a tool for correction, feedback and assessment. Test also can drive the students to work harder to achieve the goal of learning process.

In her journal also provided motivated teacher that became key of motivational factors for the students, are: teacher enthusiasm, teaches as resources, creative, and strict. It should be clear that the goal of using 
motivational strategies is to get students' motivation in learning. Teachers as the key person in the classroom have to demonstrate motivational behaviors as well as to apply motivational strategies to create an engaging learning environment.

Motivational strategies are techniques that promote the individual's goal-related behavior. Because human behavior is rather complex, there are many diverse ways of promoting it. In fact, almost any influence a person is exposed to might potentially affect his/her behavior. Motivational strategies refer to those motivational influences that are consciously exerted to achieve some systematic and enduring positive effect. Based on Cheng (2007) in his journal "The use of Motivational Strategies in Language Instruction: the case of EFL teaching in Taiwan" conclude the motivational strategies he used are: displaying motivating teacher behavior, promoting students' self-confidence, creating a pleasant classroom climate and presenting tasks properly. Those four aspects are the motivational strategies that used to arouse students' motivation in the classroom.

Also on journal conducted by Astuti (2013) 'Teacher' and Students 'Perceptions of Motivational Teaching Strategies in an Indonesian High School Context" she implemented four motivationanl strategies by Dornyei (2001) : creating the basic motivational conditions; generating initial motivation; maintaining and protecting motivation; and encouraging positive retrospective self-evaluation. The findings suggested that the teachers play a very important role in motivating their students. And also conclude the two main points of her research that (1) the teacher is a motivating factor, and (2) a relaxing and encouraging atmosphere is important in the language classroom.

\section{c. Strategies in Improving Students' Motivation in Speaking Skill}

Related to motivational strategies above, the writer tries to correlate between motivational strategies to be implemented in teaching speaking skill. As a conclusion that motivational strategies mentioned are: related to Dornyei (2001), the writer agreed that creating the basic motivational condition in the classroom is helpful in developing students' motivation. In this case the appropriate teacher behaviour is needed. The teachers should show their enthusiasm to the students, and have good relationship with the students. High tolerance between teacher and students/students and students is needed. It will create pleasant and supportive atmosphere in the classroom. When the students are secure, it will be easy to manage them during learning process.

Moreover, (Renandya: 2013) proposes four types of motivational strategies: teaching method, tasks, texts, and tests. All those aspects should be appropriate to the students need. In teaching speaking the students have target to express their ideas freely and spontaneously. The methods, tasks given, texts (material), and tests (assessment) should be appropriate to the students need in achieving the goal of the learning. Various methods can be used in teaching speaking, for instance: guessing game, performing a skit or plylete, role-play, classdiscussion/debate/seminar, speech, perform a drama, discuss a plan (group dynamic), retell/report/argue/persuade activity (Sadtono in Fahrurrazy: 2012:80).

In addition, to arouse students' motivation in teaching speaking, the teacher should know the students' interest and also their language level, because they will produce more oral production when the topic of speaking is their interest or at their language mastery. The teacher can make a careful choice of topics and tasks to stimulate the students' interest. In giving tasks, Thornbury (2005) provided some criteria for speaking task, they are:

Productivity, producing maximally spoken language in order to provide the best conditions for autonomous language use.

- $\quad$ Purposefulness, making sure that every speaking activity has a clear outcome.

- Interactivity, the tasks such as talks and presentation should be performed in situations where there is at least the possibility of interaction.

- Challenge, the task should stretch the students so they are forced to draw on heir available communication resources to achieve the outcome.

- $\quad$ Safety, the students need to feel confident, when meeting the challenges and attempting autonomous language use with supportive classroom dynamic and non-judgmental attitude.

- $\quad$ Authenticity, the task should have some relation to the real life language use.

On the other hand, in teaching speaking the teacher also can invite a native speaker if it is possible, as a model how to pronoun correctly from native. As a teacher we do not criticize too much on language and content, especially for beginner, let them concentrate on ideas. Again, the teacher should match the dialog with the social status of the speakers (students), also use small group to maximize students' involvement. And about the tests (assessment), the teacher should focus on students' ideas/comprehension, fluency, diction, accuracy, general impression. Besides, still the teacher has role as feedback provider. As a result, the teacher should remember that the goals of teaching speaking are: the students should actually talk a lot and the language used should be of an acceptable level which is relevant, easily understandable and of an acceptable level of accuracy (Ur: 2012: 117). 
Here, some researches related to motivational strategies in teaching speaking. Xu Liu (2010) on his research arousing the College Students' Motivation in Speaking English through Role-Play told that the teachers can use some communicative classroom activities such as role-play to arouse the students' motivation of English speaking. Vilma (2009) on teaching speaking through mass media argued that the importance of Media in general and in education in particular; Media are persuasive and pervasive, newspapers, magazines, radio, television and internet in the classroom, etc., and Sami Mousa (2004) on Use of English speaking Movies as a Tool for Language Acquisition and Learning by Students argued that English movie are beneficial for the students, the results show that the majority of the students do watch movies and benefit from them. This benefit is mainly shown in the authentic input they receive and the cultural aspect they learn about English speaking societies. In addition, this research shows the ways through which the students try to get the most benefit from movies, namely by doing some movie activities, such as looking up words in a dictionary, and the memorization of some language forms.

\section{Conclusion}

Motivation problem is always a tricky task for teacher to be addressed in foreign language learning process - in this case is English. The unwilling of student to be active in class is a reflection of motivation lacking. This also happens among students in higher education. So that the writer provides the information of four steps of motivational strategies to be implemented, they are: creating the basic motivational conditions (Dornyei: 2001: 31); the findings conducted by Astuti in her journal (2013): displaying motivating teacher behavior, promoting students' self-confidence, creating a pleasant classroom climate and presenting tasks properly, and Renandya (2013) Appropriate 4Ts motivational strategies (Teaching methods, Tasks, Texts, and Tests).

By implementing those motivational strategies it guide and help the student to have high motivation and help them to reach the learning process goal. However, the writer emphasizes on motivational strategies in teaching speaking, because the most complicated skill among four skills is speaking which shows the ability to express ideas. In order to address this problem, motivational strategies in teaching speaking are applied in teaching method, so that teacher can obtain the real picture of students' competencies as well as motivate students to study.

\section{References}

Astuti, 2013. “Teachers' and students' perceptions of motivational teaching strategies in an indonesian high school context"

Aydin, Selami. Factors Causing Demotivation in EFL Teaching Process: A Case Study. The Qualitative Report, Vol. 17. 2012

Bahadorfar, Maryam and Reza Omidvar. 2014. Technology in Teaching Speaking Skill. Acme International Journal of Multidisciplinary Research.

Cheng, H.F \& Dornyei Z. 2007. "The use of Motivational Strategies in Language Instruction: the case of EFL teaching in Taiwan. Innovation in Language Learning and Teaching"

Dornyei, Zoltan. 1988. Motivation in Second and Foreign Language Learning. Language Teaching, Vol.31. Cambridge University Press.

Dornyei, Zoltan. 2001 Motivational Strategies in the Language Classroom. Cambridge University Press.

Fachrurrazy. 2012. “Teaching English as a Foreign Language for Teachers in Indonesia”. State University of Malang Press.

Harmer, J. 2001. The Pracice of English Language Teaching $3^{\text {rd }}$ Edition. Pearson Education. Long Man.

Littlewood, W. 1981. Communicative language teaching. Cambridge: Cambridge University

Press.

Littlewood, W. 1984. Foreign and second language learning.Cambridge:Cambridge University Press.

Nunan, D. (2003). Practical English Language Teaching. New York: McGraw Hill

Renandya, W.A 2013. "Current Beliefs in ELT and their Implications for Language Learning and Teaching. 
Sami Mousa. Use of English speaking Movies as a Tool for Language Acquisition and Learning by Students at Imam Mohammad Ibn Saud Islamic University. 2004

Thornburry. S. 2005. “How to Teach Speaking” Pearson Education. Long Man.

Ur, P., 2012. A Course in Language Teaching. Practice and Theory. Cambridge: Cambridge University Press.

Vilma. Tafani, 2009. Teaching English Through Mass Media. Department of English, “A. Xhuvani” University, Elbasan, Albania

Walker, Colin. Managing Student Motivation through Teaching Performance. 2011.

Zhengdong Gan. Understanding L2 Speaking Problems: Implications for ESL Curriculum Development in a Teacher Training Institution in Hong Kong. 2012

Xu Lin. 2010. “Arousing the College Students' Motivation in Speaking English”. Beijing City University 